Fronek, P. \& Tilse, C. (2010). Controversy and its implications for the practice of contemporary social work in intercountry adoptions: A Korean-Australian case study. Australian Social Work, 63(4): 445-459. DOI: 10.1080/0312307X.2010.512957.

\title{
Controversy and its implications for the practice of contemporary social work in intercountry adoptions: A Korean Australian case study.
}

Patricia Fronek, Griffith University, and Cheryl Tilse, University of Queensland.

\begin{abstract}
Korean-Australian intercountry adoption (ICA) has been practised for 30 years. This longevity provides unique opportunities to develop critical perspectives on a complex, global practice. This paper presents understandings drawn from a study that explores Korean intercountry adoption using Actor Network Theory. It argues that the practice of intercountry adoption in Australia has been shaped by adoption-driven influences and characterised by controversy and competing discourses. It concludes that contemporary understandings necessitate a global, contextual and critical view that is inclusive of emerging voices and alternate discourses. The challenge for practitioners and policy makers is to ensure the complex nature of the phenomenon is understood by all stakeholders. This will involve remaining child-focused, promoting multi-level interventions, incorporating research findings and resisting wholly positive discourse that promotes singular perspectives. An awareness of how the internet is used to forge networks and promote discourses is crucial in ensuring multiple perspectives are considered in this contentious practice field.
\end{abstract}

Key words: Korean intercountry adoption, Actor Network Theory, Critical practice 


\section{Controversy and its implications for the practice of contemporary social work in intercountry adoptions: A Korean Australian case study}

Contemporary social work practice in intercountry adoption (ICA) must be understood in a global context. Approaches that seek to understand the phenomenon from one perspective such as that of prospective adoptive parents or as a wholly positive practice represent only partial understandings of a complex and controversial practice. Approaches that encompass multilayered and multifocal perspectives are needed.

ICA is not simply about the movement of children from poorer countries to wealthier nations and the subsequent adjustment of adoptive families and children. South Korea (henceforth referred to as Korea) is not a developing country; rather, it is a competing global economy whose ICA program has not diminished in the context of economic growth. A globalised view of ICA practice not only incorporates economic aspects of globalisation that include money, diplomatic and trade relations, it also encompasses the circulation of ideas, practices, and people (Fronek, 2006). Likewise, contemporary perspectives need to consider the impact of advances in technology such as the internet on the promotion of ICA, the sharing of experiences and the shaping of practice and policy responses. Ethical policies and practices for birth families, prospective adoptive parents, families formed by adoption and adoptees must be developed from a perspective that critically examines the ideas and assumptions on which policies and practices are based and the influences that continue to shape them. Only then can policies and practices be appropriately protective of vulnerable people and their children, effective and responsive to new knowledge. Understanding how ICA from particular countries emerges and spreads and how some discourses dominate over others contributes to this critical understanding. Social work practitioners and policy makers need to make sense of and incorporate these understandings at multiple practice levels to challenge discourses that present simplistic views of ICA.

Korean ICA represents a program characterised by longevity, efficiency and popularity. Approximately 180,000 Korean children have been adopted overseas to western countries such as the United States, Sweden and Australia since the Korean War (Selman, 2007). In a practice that has spanned over fifty years, (thirty years in Australia) adoptees and birth families are no longer silent actors. The longevity and size of the Korean program and its significant role in Australian ICA history provide unique opportunities to understand ICA in a way that includes emergent voices. Many adults adopted as children are now contributing to knowledge concerning ICA (Bergquist, 2007; Brian, 2007; Hubinette, 2005; Hurdis, 2007). Some Korean birth mothers, likewise, are increasingly putting forward their perspectives and experiences (Fronek 2009a) Through the internet and the support of other actors in the Korean adoption phenomena, they have found a voice that challenges current understandings of Korean Australian adoption and Australian policies, processes and practices.

The Korean adoption program is considered to be a well run program with a track record of reliability and good practices (Fronek, 2009a). However, in western countries such as Australia, beliefs concerning circumstances that prevent Korean mothers parenting their children, such as the 'orphaned' status of a child or the cultural unacceptability of unmarried motherhood, are generally not questioned 
(Fronek, 2009a). Consequently, factors such as poverty and alternative solutions that address the needs of birth families with two parents or widowed, divorced or unmarried mothers and their children differently are not well considered. There is scant research that takes a broad, critical perspective; rather the focus has primarily been on the experiences of adoptive parents and adopted children.

\section{Theoretical Framework and Context}

This paper explores contemporary and critical aspects of ICA and its implications for social work practice and future research. Understandings presented are drawn from a study (Fronek, 2009a) that used an Actor Network Theory (ANT) framework (Callon, 1986; Latour, 1987, 1988) to understand the diffusion of ICA from Korea to Australia, specifically Queensland, and its continuance. A case study design explored which actor networks were influential in the diffusion and continuance of the phenomena, from the 1970s to 2007. An analysis of documents and interview transcripts explored how these networks enabled its diffusion and influenced its continuance using key concepts in ANT. The data corpus included information gathered from interviews with key informants who were considered important to understanding the diffusion of the practice into Queensland. These were key staff from the Queensland Department of Child Safety, the New South Wales Department of Communities and members of adoptive parent and adoptee groups. Additional data sources were archival documents from the Department of Child Safety Queensland; transcriptions from the Federal Inquiry on adoption (CMW Australia, 2005); media reports; internet sources such as adoptee, government and parent group websites and computer mediated communications such as electronic discussion groups. The textual material and the interview transcripts were analysed using a thematic analysis, constant comparison and analytic methods informed by ANT. A description of the theoretical perspective and methodology is detailed in previous publications (Fronek, 2009a,b) and beyond the scope of this paper. This paper presents a brief overview of ANT as it guided the study, research findings relating to the actor networks identified, and historical and contemporary influences on ICA in both Korea and Australia, to provide a context for understanding current practice challenges and responses.

\section{Actor Network Theory (ANT)}

ANT has previously been used to understand how technological innovations spread and become accepted practice (Callon, 1986; Latour, 1988). In this study, the focus was not on the spread of a technological advancement; rather, it focused on the spread of the Korean Australian ICA phenomenon. ANT describes processes where actors, human and non human, strategically position themselves through power struggles called translations to form networks. It is during the translation process that tactics are devised to enrol new actors and ensure particular discourses are spread. Discourse can be altered during the translation process to include elements acceptable to the actor to be enrolled. A network has more strength and influence than an individual actor; goals are therefore more likely to be met and ideas, or in this case, the acceptability of ICA practice, more easily spread.

According to ANT, networks differ from networks identified in other approaches in that they are performative. Actor networks are engaged in a constant process of seeking new actors that can be convinced that network goals align with their own and are indispensible in enabling them meet those goals. A network, for example, that identifies ICA as an acceptable and preferred practice may seek to increase the 
incidence of ICA by influencing how ICA is perceived and practised in sending and receiving countries. Networks are not the same as groups identified as active in ICA such as adoptive parents, birth parents, adoptees and government and private adoption agencies in sending and receiving countries (Fronek, 2009a; 2009b). For example, proponent actors who promote a simplistic view of child rescue can be found in all groups (Fronek 2009a, b).Networks are not stagnant entities. Actors move in and out of networks creating power struggles and the need for effective and constantly applied mechanisms of enrolling others. It is the actions of networks that define them and help understand the controversy and polarised debate that has surrounded the ICA phenomenon since its emergence last century.

\section{Networks}

The analysis identified three actor networks - nonpartisans, proponents and opponents - that operated in ways that maintained the status quo, promoted the practice or inhibited the practice (Fronek, 2009a; 2009b). Networks are known by their discourse, the goals they seek to achieve and the actions they take to achieve them. As identified in the analysis, proponent discourse promotes ICA as a wholly positive practice that offers an ideal social welfare solution that meets the needs of all concerned, that is, people who seek to form families, children in orphanages or foster care, and birth families who are unable to raise their children. In this discourse, there are no losers in ICA; children are rescued by adoption. In Australia, the proponent view labels any obstacle to more expedient and less expensive adoptions as problematic. Any challenge is considered 'anti-adoption' by proponent actors. The use of anti-adoption labelling became a tactic used in power struggles (translation processes) that proved attractive to and effective in engaging new actors in the past decade.

In contrast, opponents oppose the practice of ICA in all circumstances for a range of reasons including racism and concerns about exploitation of children and birth families. Nonpartisans do not hold the polarised positions of either opponents or proponents. Power struggles ensue when attempts are made to enrol actors from other networks. Successful enrolments were found to occur at key junctures such as the federal Inquiry (CMW Australia, 2005Fronek, 2009a; 2009b).

Previous works informed by different theoretical perspectives have identified groups concerned with ICA defined by value positions held (Fronek, 2009a,b). Masson (2001) identified promoters, abolitionists, and pragmatists. Their value positions share some similarities with proponent, opponent and nonpartisan discourse. Although nonpartisans share aspects of pragmatism, unlike pragmatists, nonpartisan discourse is more than a practical, neutral approach to ensuring legal standards are maintained in ICA practice. Nonpartisans, like many opponents, incorporate complexities in their understandings. These include the factors that contribute to child relinquishment inherent in ICA practice and the risks such as child trafficking. Social workers, like members of other groups, can be positioned as nonpartisans, proponents or opponents each claiming they are advocates for complex understandings and child centred practices. Like all actors, they can change these positions to meet particular goals. Networks in Australia and their actions were found to cross national borders and were indeed global. A critical approach examines opposing network influences on the ICA phenomena in both Korea and Australia. 


\section{Network influences}

After the Korean War, ICA quickly became a welfare solution for 'abandoned' children (Huh, 1993; Lee, 2007). Other programs that promoted alternative welfare strategies such as helping families stay together did not grow to the proportions or popularity of ICA (Miller, 1971). An identified reason for the relinquishment of children is cultural rejection of children born outside of traditional Korean family formations (Sarri et al., 1998). The discourse of cultural rejection is accepted by receiving countries as well as supported by those promoting adoption in Korea. Although the concept of illegitimacy is now generally acceptable in western countries, the pathologising of unmarried motherhood features in the history of domestic adoption in countries such as the USA, UK and Australia (Ellison, 2003; Herman, 2002; Reeves,1993; Sokoloff, 1993). Recent research shows that not all Korean birth mothers were or are unmarried in the western sense of the word (D. S. Kim, 2007). Many children were adopted as a result of poverty and lack of adequate welfare provision to birth mothers and families. Domestic adoption was not well developed in Korea. In the past decade the Korean government has put considerable effort and incentives into promoting cultural change regarding domestic adoption (Baik and Chung, 1996). This has not been matched by policies and programs that support the ability of mothers, single, married, divorced, widowed or simply poor, to raise their children.

An increase in work on Korean ICA has expanded the existing body of knowledge (Bergquist et al., 2007; Hubinette, 2005; Trenka et al., 2006). These works provide fresh views of the enabling conditions for the emergence of the ICA phenomenon from the 1950s and the influential champions and networks promoting the cause of child adoption. Although the Korean government has for decades outlined plans to cease its ICA program, the date for cessation has constantly moved forward, the latest estimate being 2015 (Hubinette, 2005). There are a number of reasons that contribute to the continuation of ICA practice. Perhaps the most influential is the political pressure placed on Korea by proponents in receiving countries whenever the number of children adopted overseas decreases (Choy, 2007; Hubinette, 2005). In addition, ICA offers the Korean government an economically viable welfare solution, that is, a program that is less costly than foster care programs or those that would adequately support families to keep their children. Despite a six months moratorium on new applications at the beginning of 2007 and reduced numbers of children adopted from Korea since that time, the program continues (Fronek, 2009a; AIHW, 2009).

Korea has developed a domestic adoption program to replace ICA (Byma, 1974; Penner, 1996; Sarri et al., 1998). Korean-based organisations campaign to promote domestic adoption while the Korean government has introduced a range of financial incentives and relaxed selection criteria for prospective Korean parents to encourage Koreans to adopt domestically (Fronek, 2009a). It is assumed that domestic adoption will replace international adoption. To date, this has not been achieved, suggesting other influences are at play in the continuance of ICA. Moments in history where the numbers of children adopted dramatically fluctuated such as the declines following the Asian and Olympic games in the 1980s (Sarri, 1998, Hubinette, 2005) are attributable to winners and losers in power struggles (Fronek, 2009a). Simplistic understandings do not take into account how power is enacted between divergent interests. 
Some authors suggest that though percentages have declined, the actual numbers of both domestic and ICAs increased until 2007 (Kim, 2007; Lee, 2007). Selman (2009) reported that the total numbers of ICAs from Korea declined in 2006 and 2007. Since then, the actual numbers of domestic adoptions exceeded ICAs by 123 in 2007 and 56 in 2008 (Selman 2009b). He attributes this to the decline of ICAs from Korea rather than an increase in Korean domestic adoptions (Selman 2009b). It has been argued that the practice of ICA itself has prevented Korea from developing its own solutions for children and families who require assistance due to poverty, lack of adequate welfare programs, and cultural and legal barriers experienced by birth mothers and families (Byma, 1974; Sarri et al., 1998). The pursuit of domestic adoption as a replacement phenomenon and sole alternative ignores the social issues which create the need for adoption in the first place and belies the influence of those networks that promote the practice of ICA at a local and international level.

Additional voices are now being inserted into understandings of ICA. The views of birth mothers emerged in the data via the internet and the media. An example of this, circulated via email discussion groups and internet sites, is a 2005 Korean television production that outlines a range of issues about adoption practices from the perspectives of birth mothers and adoptees (http://www.youtube.com/watch?v=1Rfygpzugkk\&feature=related). Their experiences are also described in the literature (Kim H, 2005; 2007). Korean mothers have formed groups such as Mindeulae (Dandelions) and Miss Mamamia connected via the Internet (http://www.birthmothersmeeting.com;

http://koreanunwedmoms.blogspot.com): Many of Korea's adopted children are now adults connected through organisations such as ASK (Adoptee Solidarity Korea, http://www.adopteesolidarity.org) and TRACK (Truth and Reconciliation for the Adoption Community of Korea, http://justicespeaking.wordpress.com ). Eleana Kim (2003) reported that by 2003 approximately 2,000 adult adoptees return to Korea to live every year and many are engaged in western style political action concerning the practice of ICA (Hubinette, 2004). A global network has formed of these Korean born adults (Freundlich and Lieberthal, 1999; Hubinette, 2004; Kim, 2005). Some birth mothers have found their voice with them

(http://www.youtube.com/watch?v=1Rfygpzugkk\&feature=related) and some adoptive parents have joined them (http://www.youtube.com/watch?v=a9p-ohslFag). The internet features strongly in the spread of these discourses. Opponents seek appropriate actions that redress the problems in ICA, provide for the needs of children and their birth mothers and call for the cessation of Korean ICA. In this discourse, ICA is identified as a phenomenon fraught with ethical and welfare issues that are not adequately addressed. However, not all adoptees, birth mothers or adoptive parents are opponent, some are proponents who seek its continuance if not its growth whereas some are identified as nonpartisans.

In receiving countries such as Australia, the proponent network is working in opposition to emergent opponent voices and nonpartisan positions. Australian social workers, policy makers and prospective adoptive parents are primarily exposed to pressure from proponent actors. Activities of those actors in Korea seem somewhat removed from daily business. Geography, however, has not been an inhibitor to growth of the proponent network and Western influences. Western influence on the practice of ICA from Korea has been present from the 1950s (Hubinette, 2005). Western style orphanages were established, followed by the drive to first rescue 
children from war, then life in an orphanage. There is clear evidence of pressure from parent groups in countries such as the United States, Sweden and Australia to continue the practice when faced with slow downs or temporary cessations (Choy, 2007; Fronek, 2009a; Hubinette, 2005). The size of the Korean program and the precedent it has established as an efficient program has meant current threats to the continuation of the program in Australia have created tensions for many hoping to adopt a child internationally and for proponents promoting it. Selman (2006; 2009a) argued that some countries may be put under increased pressure to release their children for international adoption if other sources become less accessible and highlights how this may increase the risk of trafficking. This is particularly relevant as the majority of children adopted into Australia are from Korea and China, countries that have not ratified international conventions on adoption and are therefore not subject to these safeguards (Fronek, 2009a). China opened its doors to Australia in 1999 in response to proponent influence from parent groups and particular politicians placing pressure on governments (Fronek, 2009a, b). Current pressure to release children for adoption, to expedite processes and locate new sources of children for adoption is concerning. ICAs are increasing worldwide (UN, 2009) most notably between non Hague countries and those countries where proponent discourse has wielded the most influence on ICA practice. The influences of particular networks and their struggles to increase these influences mean that Korean ICA can no longer be seen as a benign practice. The growing opponent network that now includes birth mothers, some adoptees, some adoptive parents and some academics, highlights the circumstances of birth families and the lack of services available to them. It is this network that challenges the actions of proponents in the continuance of ICA.

\section{The Australian context}

The impact of threats to adoption programs on proponent goals, their response to these threats, and the implications on the global practice of ICA can be understood using the Australia experience. Korean adoption is important in Australia as Korean children have represented the majority of children adopted into Australia every year until 2003-4 when China took the lead in choice of country for Australian adoptive parents (AIHW, 2004). The Korean program to Australia has been reliable and well run with only a few occasions in its history where the numbers of children adopted into country have slowed. The most recent of these has been the slow down commencing from 2007 (Fronek, 2009a). China has since placed greater restrictions on its international program. The Ethiopian program was also recently under suspension, although this was lifted in April 2010.

The numbers of ICAs to Australia have remained relatively stable until the decline from 2007 with 269 ICAs reported in 2008-09 compared to 421 in 2005-6 (AIHW, 2006; 2009; 2010; Kelly, 2000). This decrease is attributed to the changes in the China and Korean programs (AIHW, 2009). These conditions mobilise proponents as their goal of child adoption is seriously threatened. This pressure, enacted in attempts to enroll new actors as proponents, is directed at politicians, policy makers, government agencies, human service practitioners and at the Korean adoption agency that deals with Australia with the aim to increase the numbers of children to Australia. The Korean adoption agency, Eastern Child Welfare Society, is not the decision maker regarding the number of children made available for ICA. Quotas are determined by the Korean government and the adoption agency simply provides an 
adoption service and a central point of communication between the Korean and Australian governments.

There is a paucity of research that helps understand the institutionalisation of Korean ICA in Australia and the impact of contemporary issues that threaten its existence. It diffused into the country in the 1970s, over 20 years after the Korean War ended, at a time when paradoxically Korea was planning to cease its adoption program by 1981, and the Korean economy was rapidly growing. Australia was ill prepared for the phenomenon in legislative and policy terms as Australian states lacked legislative and policy frameworks. In Australia, adoption is subject to state rather than federal legislation. A lack of uniform regulations remains an issue to this day (Boss, 1992; Fopp, 1982, CMW Australia, 2005).

The 1970s saw a dramatic decline in domestic adoptions in Australia. The total number of domestic adoptions reached a peak of 10,000 in 1971-1972 compared to only 60 in 2005-6 (AIHW, 2006; Kelly, 2000). This drop in numbers is attributed to changes in fertility control, welfare support for lone parents and changed social attitudes towards unmarried parenthood. It is this decline and Australia's involvement in the Vietnam War that influenced the institutionalisation of Korean ICA in Australia. In 1975, children were airlifted from Saigon to the United States, Canada and Australia in dramatic and controversial circumstances (Bergquist, 2009; Brookfield, 2009; Harvey, 1982, 1983; Spence, 1975; Zigler, 1976). Operation Babylift, as it was known, provided an early Australian experience of adopting children in crisis from overseas that was sanctioned by government. Operation Babylift came about as a result of the actions of influential US adoption agencies founded in Korea to airlift children already in the adoption system to their adoptive families in the West. It was the actions of proponent networks that emerged during the Korean War that enabled Operation Babylift and the subsequent diffusion of Korean adoption into Australia by 1977, two years after Operation Babylift (Fronek, 2009a, 2010). Prior to the 1970s adopting a child of a different cultural origin from overseas was the exception in Australia (Harvey, 1983). English (1990) reports from practice experience that prior to 1975 less than fifty couples would have enquired about adopting a child from overseas and when they did it was usually relating to a specific child.

Policy change in the 1970's in Australia influenced the acceptability of ICA as a practice. After World War II, Australia was a relatively homogenous society with a focus on British and European migration. In the 1970s it was transitioning from a society with an official immigration policy of The White Australia Policy to a multicultural and multi-racial society (Batrouney and Stone, 1998; Castles, 2002). The decline of The White Australia Policy paralleled the emergence of Multiculturalism as an ideology and as policy in 1973 (Lopez, 2000). Ideological and political change against a backdrop of Australia's involvement in the Korean and Vietnam Wars and Cold War politics created local conditions conducive to the diffusion of ICA, specifically the adoption of children from Asia, and the dominance of proponent discourse.

Parent groups organised, spokespersons emerged and sought political influence. Parent groups in Australia began with proponent goals, that is, to promote the expansion of ICA and to influence legislation and policies to enable it. In the 1970s, 
parent groups were noted to be politically powerful influencing the political direction of ICA practice in Australia (Fopp, 1982). The first group was formed in New South Wales in 1974 by parents who had succeeded in adopting children from overseas. They sought to assist other prospective parents to do the same (Calder, 1979; Gray, 1997). Parent groups pressured authorities, lobbied the media, and in some cases found ways to adopt children outside the legal and welfare systems (Calder, 1979). The risks created by these practices forced the Australian federal and state governments to take action to safeguard the interests of children as well as those seeking to adopt. This took the form of legislative reform, the establishment of authorities for ICA, the development of policies and procedures, and the negotiation of bilateral agreements with sending countries. The strength of proponent influence enabled conditions where Korea has never signed a government to government bilateral agreement with Australia. Instead, Eastern Child Welfare Society (not the Korean government) signed working arrangements with Australian States. The Korean government has officially distanced itself from the Korean Australian program from its inception. Australia did not ratify the Hague Convention Protection of Children and Cooperation in Respect of ICA until the 26th August 1998. Australia's ratification of the Convention, however, was not an impediment to establishing the adoption program with China in 1999, a non Hague signatory. Korea has never been a signatory to this Convention.

Proponents in Australia include many parent groups and adoptive parents in the network. Parent support groups began promoting the practice; a position that has been mostly maintained since the 1970s. There are, however, many proponent actors also identified in the ranks of adoptees, government policy makers, social work practitioners, politicians and more recently Australian celebrities (e.g. Furness, wife of actor, Hugh Jackman and adoptive parent). ANT posits that actor networks achieve longevity and influence by recruiting those who can best help the network achieve its goals. Actor networks can encompass a range of ideological positions but adhere to particular network goals such as the promotion of ICA and the use of particular tactics such as anti-adoption labelling to counteract perceived threats. In the analysis of the textual material and interview transcripts, the proponent network was found to be one that has dominated in the Australian context. The internet, an efficient means of mobilising discourse, provides links between proponent actors in Australia and overseas. The internet has provided a strong forum for proponent and opponent discourse. What is less evident in the analysis was Australian nonpartisan discourse. When it was identified, anti adoption labelling emerged in the power struggles effectively silencing more complex perspectives. A number of tactics used by proponent actors in Australia during the 1970s proved effective over the thirty years of ICA practice. These tactics were able to counter alternate discourse, recruit new actors, spread ideas accepted as fact and influence others who were influential in practice and policy development. The use of such tactics and subsequent enrolments of new actors converged in 2005 at the Federal Inquiry (CMW Australia, 2005). The Inquiry resulted from the actions of some politicians who adopted and championed proponent discourse aligned with political objectives.

Proponent discourse evident during the Inquiry portrayed child rescue by adoption as a necessary child welfare strategy where there were no losers. ICA was portrayed as a wholly positive practice in Australia with no negative aspects or complexities requiring consideration. It perpetuated assumptions that there were millions of 
orphans in the world requiring adoption. A media report from UNICEF (http://www.unicef.org/media/media_45279.html) explains that that the definition of 'orphan' used for statistical purposes differs from a western understanding and that the majority of children identified as orphans may have one surviving parent and certainly other family members. The report identifies that the focus on individual children inhibits the development of capacity in communities to care for their children. Proponent discourse did not incorporate these complexities and espoused that the Australian government should take all steps necessary to open the doors of new sending countries to Australia. Any perceived obstacle to the spread of ICA practice was labelled 'anti adoption' (Fronek 2009a; 2009b). This concept lacks definition yet as a tactic proved an effective means of silencing more complex understandings of the practice. The analysis of the transcripts of the Inquiry identified that politicians engaged in this process readily adopted proponent discourse. The discourse, however, changed subtly to incorporate the goals of the new actors enrolled, that is, the politicians serving on the Inquiry, and to create new ways of responding to threats, that is, locating a new source of children. These children were to be adopted locally from foster care, a welfare approach noted by Dickens (2009) as characteristic of liberal and neoliberal welfare strategies. It is yet to be seen if Australian proponents will support such a detour.

The practice of ICA in Australia has proven since its inception to be controversial, political and subject to proponent influences that are adoption-driven. Current threats to continuance are threats of closure and developing opponent activities. Proponent goals may not be easily met in this climate. The numbers of Korean adoptions are currently reducing. Likewise, other sending countries have also been subject to influences that open and close their doors, limiting alternative sources. It has been argued that these factors cannot be understood through simplistic discourses such as orphan rescue or anti adoption labelling.

\section{Implications for practice}

This paper highlights current controversies that raise considerations for policy development, social work practice and future research in ICA. There is currently no research that determines how well practitioners, prospective parents and adoptive families understand these dilemmas and how well armed they are to deal with these issues that will inevitably arise in a globalised context.

Understanding these controversies differently throws new light on political influences concerning ICA, subsequent policy development, and practice with birth families, prospective parents, families formed by adoption, and adoptees. For example, facilitating adoptions for children with immediate or extended families who are living in orphanages to take advantage of food and/ or education may not be the best solution for the child, his/her family or community. A community development focus, may better meet the needs of the child, family and community. The implications, however, are that local and international policies and practices that support such approaches would not meet the needs of prospective parents raising issues for receiving countries such as Australia.

An understanding of the conflicting discourses spread by global networks is often missing from pre and post adoption services in Australia. ICA is not simply a process of application, assessment, allocation of children to prospective parents, and post 
adoption assessment and support. It is important that prospective parents, adoptive parents and adoptees are adequately prepared to deal with multiple perspectives and political action in the global arena. Highlighting the complexities denied by proponent discourse is important to this preparation. Global communications such as the internet reduce the geographical and communication barriers previously placed between sending and receiving countries and the people personally affected by ICA. Exposure to conflicting network discourses via these means is inevitable. The use of the internet to promote nonpartisan views was not strongly present in the data collected up to 2007, yet was widely used by proponent and opponent actors to circulate particular discourse. It is important for social workers to consider the role of the internet in this area of practice.

ICA policy in Australia has historically been driven by political agendas and adoption-driven discourse. Such discourse holds popular appeal while Australian research on which to base policy initiatives has been sparse. Adoption brings positive outcomes for many children and has a place as a service for children. It is not, however, a wholly positive or one dimensional phenomenon nor is it necessarily the preferred option. Research is needed to understand how and why children become available for adoption in sending countries and to explore alternative solutions that address the issues at its source.

The voices of Korean birth mothers and adults adopted from Korea as children must be heard and considered rather than marginalised. The practice of Korean ICA cannot be understood as a one dimensional action of child rescue. Nor can it be understood simply from the perspectives of receiving countries and proponent actors in the West. A contemporary approach to ICA practice in Australia would reflect this complexity, remain child focused and resist adoption-driven influences also noted in other Australian research (Murphy et al, 2009). Success cannot be measured by the number and speed of adoptions achieved. The challenge remains for the Korean government to adequately address the social and welfare factors that make children available for adoption in the first instance. Likewise, adoption-driven practices pose risks that standards will be compromised in the quest for new international or domestic sources of children, the perspectives of the disenfranchised will be overridden, and alternate solutions will not be explored. A critical, global understanding of the practice of ICA is necessary if these concerns are to be appropriately addressed. Social workers have an important role to play in putting forward a critical and contextual understanding of the complexities of ICA policies and practice.

\section{Acknowledgements}

This paper is based on work completed as a doctoral candidate at the University of Queensland. The authors would like to acknowledge Associate Professor Karen Healy for her support of this paper and to the people and organisations who participated in this research. 


\section{References}

AIHW. (2004). Adoptions Australia 2003-2004, no. AIHW cat. no. CWS 23.

Canberra: Australian Institute of Health and Welfare (AIHW).

AIHW. (2006). Adoptions Australia 2005-06, Child Welfare Series no 39. Cat. no. CSW 27. Canberra: Australian Institute of Health and Welfare (AIHW).

AIHW. (2009). Adoptions Australia 2007-08, no.46.Cat. no.CWS.34. Canberra: Australian Institute of Health and Welfare (AIHW).

AIHW. (2010). Adoptions Australia 2008-09. Child Welfare Series 48. Cat. no. CWS 36. Canberra: Australian Institute of Health and Welfare.

Baik, Y. and Chung, J. Y. (1996). Family policy in Korea. Journal of Family and Economic Issues, 17(1), 93-112.

Batrouney, T. and Stone, W. (1998). Cultural diversity and family exchanges, paper presented at the Changing Families, Challenging Futures, 6th Australian Institute of Family Studies Conference, Melbourne.

Bergquist, K. J. S. (2007). Once upon a time: A critical look at how children's literature contextualizes adoption for Asian adoptees, in Bergquist, K. J. S.; Vonk, M. E.; Kim, D. S. and Feit, M. D. (eds), International Korean Adoption: A Fifty-Year History of Policy and Practice, New York, The Haworth Press, p. 295-313.

Bergquist, K. J. S. (2009). Operation Babylift or Babyabduction?: Implications of the Hague Convention on the humanitarian evacuation and 'rescue' of children. International Social Work, 52(5), 621-633.

Bergquist, K. J. S., Vonk, M. E., Kim, D. S., and Feit, M. D. (2007). International Korean Adoption: A Fifty-Year History of Policy and Practice, New York, The Haworth Press.

Boss, P. (1992). Adoption Australia, National Children's Bureau of Australia Inc.

Brian, K. (2007). Choosing Korea: Marketing 'multiculturalism' to choosy adopters, in Bergquist, K. J.S.; Vonk, M. E.; Kim, D. S. and Feit, M. D. (eds), International Korean Adoption: A Fifty-Year History of Policy and Practice , New York, The Haworth Press, p.61-78.

Brookfield, T. (2009), 'Maverick Mothers and Mercy Flights: Canada's Controversial Introduction to International Adoption'. Journal of the Canadian Historical Association, 19(1), 307-30.

Byma, S. (1974). Overseas adoptions threaten development of local services. Canadian Child Welfare News, 50(3), 7-11. 
Calder, R. (1979). Inter-country adoption from the point of view of adoptive parents, paper presented at the Proceedings of a Seminar on Intercountry Adoption and Sponsorship, Shaping the Future for our Children, ICSW Asia and Western Pacific Regional Conference, Melbourne, Australia.

Callon, M. (1986). Some elements of a sociology of translation: domestication of the scallops and the fishermen of St Brieuc Bay, in Law, J. (ed), Power, Action, and Belief: A New Sociology of Knowledge?, London, Routledge, Kegan and Paul, p.196-233.

Castles, S. (2002). Migration and community formation under conditions of globalization. International Migration Review, 36(4), 1143-1168.

Choy, C. C. (2007). Institutionalizing international adoption: The historical origins of Korean adoption in the United States, in Bergquist, K. J. S.; Vonk M. E. and Feit, M. D. (eds), International Korean Adoption: A Fifty-Year History of Policy and Practice, New York, The Haworth Press, p.25-42.

CMW Australia, (2005). Overseas Adoption in Australia: The Report on the Inquiry into Adoption of Children from Overseas, Canberra.

Dickens, J. (2009). Social policy approaches to intercountry adoption. International Social Work, 52(5), 595-607.

Ellison, M. A. (2003). Authoritative knowledge and single women's unintentional pregnancies, abortions, adoption, and single motherhood: Social stigma and structural violence. Medical Anthropology Quarterly, 17(3), 322.

English, B. A. (1990). Inter-country adoption: the context of recent developments and the need for research. Children Australia, 15(1), 16-20.

Fopp, P. A. (1982). Inter-Country Adoption - Australia's Position, Australian Journal of Social Issues. 17(1), pp. 50-61.

Freundlich, M. and Lieberthal, J. K. (1999). The gathering of the first generation of adult Korean adoptees: adoptees perceptions of international adoption. www.adoptioninstitute.org/proed/korfindings.html, retrieved 3rd January, 2004.

Fronek, P. (2006). Global perspectives in Korean intercountry adoption. Asia Pacific Journal of Social Work and Development, 16(1), 21-31.

Fronek, P. (2009a). Understanding the Emergence, Diffusion and Continuance of Intercountry Adoption from South Korea to Queensland, $\mathrm{PhD}$, Brisbane, Australia, University of Queensland, http://espace.uq.edu.au/view/UQ:180158.

(2009b), Intercountry adoption in Australia: A natural evolution or purposeful actions, in Sparkes, C. and Cuthbert, D. (eds), Other People's Children: Adoption in Australia, Melbourne, Australia: Australian Scholarly Publishing Pty Ltd, 37-54. 
Fronek, P. (2010). The institutionalisation of Korean adoption in Australia: A legacy of the Vietnam War, The Vietnam Inheritance: Cultural, Social and Political Legacies of the Vietnam War in Australia: An Interdisciplinary Symposium Marking the 35th Anniversary of the End of the War, 29 $9^{\text {th }}-30$ th April, Monash University, Melbourne.

Gray, C. (1997). Intercountry Adoption and Parent Support Groups. Research Report 6, (No. 6), NSW, Law Reform Commission (NSW).

Harvey, I. (1982). Transracial adoption in Australia. Adoption and Fostering, 6(1), 43-49.

Harvey, I. (1983). Adoption of Vietnamese children: An Australian study. Australian Journal of Social Issues, 18(1), 55-69.

Herman, E. (2002). The paradoxical rationalization of modern adoption. Journal of Social History, 36(2), 339.

Hubinette, T. (2004). Adopted Koreans and the development of identity in the 'Third Space. Adoption and Fostering, 28(1),16-24.

Hubinette, T. (2005). Comforting an Orphaned Nation: Representations of International Adoption and Adopted Koreans in Korean Popular Culture, Stockholm, Stockholm University.

Huh, N. S. (1993). Services for out-of-wedlock children in Korea. Early Child Development and Care, 85, 35-46.

Hurdis, R. (2007). Lifting the Shroud of Silence: A Korean adoptee's search for truth, legitimacy, and justice, in Bergquist, K. J. S.; Vonk, M. E.; Kim, D. S. and Feit, M. D. (eds), International Korean Adoption: A Fifty-Year History of Policy and Practice, New York, The Haworth Press, p171-185.

Kelly, S. (2000). Adoption in Australia - An Overview, paper presented at the Family Futures: Issues in Research and Policy, 7th Australian Institute of Family Studies Conference, Sydney, Australia.

Kim, D. S. (2007). A country divided: Contextualizing adoption from a Korean perspective, in Bergquist, K. J. S.; Vonk, M. E., Kim, D. S. and Feit, M. D. (eds), International Korean Adoption: A Fifty-Year History of Policy and Practice, New York, Haworth Press, p.3-23.

Kim, E. (2003). Wedding citizenship and Culture: Korean adoptees and the global family of Korea. Social Text 74, 21(1), 57-81.

Kim, H. (2007). Mothers without mothering: Birth mothers from South Korea since the Korean War. In K. J. S. Berquist, M. E. Vonk, D. S. Kim \& M. D. Feit (Eds.), International Korean Adoption: A Fifty-Year History of Policy and Practice (pp. 131-153). New York: The Haworth Press. 
Kim, H. (2007). A flickering motherhood: Korean birthmothers' internet community 5(2) http://www.barnard.edu/sfonline/blogs/kim_01.htm .

Latour, B. (1987). Science in Action, Cambridge, Massachusetts, Harvard University Press.

Latour, B. (1988). The Pasteurization of France (Sheridan, A \& Law, J., Trans.), USA, Harvard University Press.

Lee, B. J. (2007). Recent trends in child welfare and adoption in Korea challenges and future directions, in Bergquist, K. J. S.; Vonk, M. E.; Kim, D. S. and Feit, M. D. (eds), International Korean Adoption: A Fifty-Year History of Policy and Practice, New York, The Haworth Press, p.189-206.

Lopez, M. (2000). 'The politics of the origins of multiculturalism: Lobbying and the power of influence. People and Place, 8(4), 22-28.

Masson, J. (2001). 'Intercountry adoption: A global problem or a global solution?', Journal of International Affairs, 55(1), 141-166.

Miller, H. (1971). Recent developments in Korean services for children. Children, 18(1), p.28.

Murphy, K., Quartly, M., \& Cuthbert, D. (2009). In the best interests of the child: The re-emergence of pro-adoption discourses in Australia. Australian Journal of Politics and History, 55(2), 201-218.

Penner, E. (1996). Comparative Analysis of International Child Adoption Practices and Policies in Korea and China, Masters Thesis in Social Work, Montreal, Quebec McGill University.

Reeves, J. (1993). The deviant mother and child: The development of adoption as an instrument of social control. Journal of Law and Society, 20(4), p. 412-426.

Sarri, R., Baik, Y., \& Bombyk, M. (1998). Goal displacement and dependency in South-Korean - United States intercountry adoption. Children and Youth Services Review, 20(1/2), pp. 87-114.

Selman, P. (2006). Trends in intercountry adoption: analysis of data from 20 receiving countries, 1998-2004. Journal of Population Research, 23(2), 183-204.

Selman, P. (2007). A demographic history of intercountry adoption, paper presented at the Moving Cultures, Shifting Identities Conference, Adelaide, Australia.

Selman, P. (2009). The rise and fall of intercountry adoption in the 21st century. International Social Work, 52(5), 575-594.

(2009b). Intercountry adoption, research, policy and practice. Table 15.5. In G. Schofield \& J. Simmonds (Eds.), The Child Placement Handbook:

Research Policy and practice. London: Sage, p.228. 
Sokoloff, B. Z. (1993). Antecedents of American adoption. The Future of Children, 3(1) 17-25.

Spence, S. (1975). Some considerations on the adoption of Vietnamese children: An international social welfare issue. International Social Work, 18(4), 10-20.

Trenka, J. J., Oparah, J. C. and Shin, S. Y. (2006). Outsiders Within: Writing on Transracial Adoption, Cambridge, Massachusetts, South End Press.

UN. (2009). Child Adoption: Trends and Policies. New York: Department of Economic and Social Affairs, Population Division, UN.

Zigler, E. (1976). A developmental psychologist's view of operation babylift. American Psychologist, 31(5), 329-340. 